\title{
Nordiques
}

$37 \mid 2019$

Mythes et réalités de l'Arctique

\section{Arctic Norway in the Russian fin-de-siècle imagination: Evgeni Lvov-Kochetov's travelogue Out in the Arctic Sea (1895)}

Tintti Klapuri

\section{(2) OpenEdition \\ Journals}

Electronic version

URL: http://journals.openedition.org/nordiques/382

DOI: 10.4000/nordiques.382

ISSN: 2777-8479

Publisher:

Association Norden, Bibliothèque de Caen la mer

\section{Printed version}

Date of publication: 1 May 2019

Number of pages: $25-36$

ISBN: 979-1-0959140-3-7

ISSN: 1761-7677

Electronic reference

Tintti Klapuri, "Arctic Norway in the Russian fin-de-siècle imagination: Evgeni Lvov-Kochetov's travelogue Out in the Arctic Sea (1895)", Nordiques [Online], 37 | 2019, Online since 31 October 2020, connection on 13 March 2021. URL: http://journals.openedition.org/nordiques/382 ; DOI: https:// doi.org/10.4000/nordiques.382 


\section{Arctic Norway in the Russian fin-de-siècle imagination: Evgeni Lvov-Kochetov's travelogue Out in the Arctic Sea (1895)}

Tintti Klapuri*

\section{RÉSUMÉ}

Dans cet article, j'analyse la perception de la Norvège arctique dans l'imaginaire russe au tournant du siècle dans un cas exemplaire, le récit de voyage Po Studenomu moriu. Poezdka na sever (Autour de la mer glaciale. Voyage dans le Nord, 1895) publié par l'écrivain-journaliste Evgeni Lvov-Kotchetov. Le livre relate l'expédition dans la Russie et la Norvège septentrionales dirigée par le ministre des Finances Serge Witte. Il montre à quel point l'entourage de Witte perçoit la Norvège arctique et le Finnmark en particulier comme une partie intégrale de l'Europe en termes culturels et sociétaux. Pour eux, il s'agit un trait distinctif par rapport à la région de Murman que le récit de voyage représente telle l'arrière-cour de la Russie impériale. Dans la narration, la Norvège arctique est perçue la plupart du temps comme un modèle positif à suivre dans la modernisation du nord de la Russie, bien que certains aspects comme le tourisme de masse soient aussi considérés avec scepticisme.

\section{ABSTRACT}

In this article, I discuss the ways in which Arctic Norway was perceived in the Russian imagination at the turn of the twentieth century in light of one representative example, the travelogue Po Studenomu moriu. Poezdka na sever (Out in the Arctic Sea. A Journey to the North, 1895), written by journalist-writer Evgeni Lvov-Kochetov. This travelogue describes Minister of Finance Sergei Witte's expedition to the Russian Far North and Northern Norway in 1894. In Lvov-Kochetov's description, the participants of Witte's entourage view Arctic Norway, Finnmark in particular, as an integral part of Europe both in cultural and societal terms. In their view, this is what distinguishes Finnmark from the neighbouring Russian North, the Murman area, which in the travelogue is represented as the backyard of the Russian Empire. In the narration, Arctic Norway is in the main seen as a positive model for the future economic modernisation of the Russian North, even if some dimensions of modernisation, such as the development of mass tourism, are viewed sceptically.

* Acting Senior Lecturer at the Department of Russian Language and Literature at the University of Helsinki and Adjunct Professor at the Department of Comparative Literature, University of Turku, Finland. 
The perception of Arctic areas in the national imagination is related in an important way with narratives written by travellers to the North. Scientific explorers, governmental figures and writers have contributed to the ways in which sparsely inhabited areas with rich natural resources have from the eighteenth century on been viewed as promising sites for colonisation ${ }^{1}$. Late nineteenth-century travel narratives on the Russian Far North, the Murman area ${ }^{2}$ in particular, are one example of how the Arctic has been narrated in terms of modernisation and colonisation. These narratives can be seen as an important phase in the Russian Arctic discourse, i.e. the governmental and scientific interest in the country's Arctic areas and their hidden potential for the Russian Empire and, later on, for the Soviet Union ${ }^{3}$. In some of these accounts, such as Evgeni Lvov-Kochetov's travelogue Out in the Arctic Sea. A Journey to the North (Po Studenomu moriu. Poezdka na sever, 1895) concerning the Russian Minister of Finance Sergei Witte's journey to the Barents area, Northern Norway with its highly-developed infrastructure is seen as a model for future modernisation of the Russian Far North.

In this article, I look at the ways in which Arctic Norway is represented in LvovKochetov's travelogue in the discursive context of Russian modernisation. As Lilya Kaganovsky observes, the expeditions to the Arctic regions have in the Russian imagination been closely tied to the project of modernity, particularly during the twentieth century ${ }^{4}$. I discuss Lvov-Kochetov's travel notes as an early example of Russian and Soviet Arctic conquest, osvoenie Arktiki, which began with full force in the 1920s, when the new state was constructed and Soviet ideology expanded to cover areas that had previously been only on the outskirts of governmental interest. As an enterprise organised by the Russian government, the journey represents to my mind one of the early steps in the process of governmental colonisation and industrialisation of the Russian European Far North, which is in Lvov-Kochetov's travelogue associated with Scandinavian societal modernisation.

1 Sverker Sörlin, "Rituals and Resources of Natural History: The North and the Arctic in Swedish Scientific Nationalism", in Narrating the Arctic. A Cultural History of Nordic Scientific Practices, M. Bravo and S. Sörlin (eds.), Canton (MA), Science History Publications, 2002, p. 73-122.

2 Today the area is usually referred to as the Murmansk region.

3 See Paul R. Josephson, The Conquest of the Russian Arctic, Cambridge (MA) - London, Harvard University Press, 2014, p. 21-22.

4 Lilya Kaganovsky, "The Negative Space in the National Imagination: Russia and the Arctic", in Arctic Environmental Modernities. From the Age of Polar Exploration to the Era of the Anthropocene, L.-A. Körber et al. (eds.), Cham, Palgrave Macmillan (Palgrave Studies in World Environmental History), 2017, p. 169-182. 


\section{NorThern ScandinaVia AND RuSSIAN MODERNISATION IN THE LATE 1800S}

The 1880s and 1890s were an important period in the modernisation of Russia, both in terms of society and culture, and Western models were both sought and criticised ${ }^{5}$. One dimension of this "catching up with Europe" that was taking place at the time was the keen interest in the developments of Scandinavian society and culture. Scandinavian literature was being translated into Russian, and its societal and emancipatory aspects were actively discussed in Russian literary circles and journals ${ }^{6}$. Within the visual arts, the interest in Scandinavia can be seen, for instance, in the exhibitions on Scandinavian and Finnish art that were organised in St. Petersburg in 1897 and $1898^{7}$.

The Arctic regions of Scandinavia were somewhat peripheral for this interest. However, during the latter half of the nineteenth century, in Russian governmental circles particular attention was paid to the Norwegian area of Finnmark. It was becoming awkwardly apparent that despite similar natural conditions, Norway had succeeded in colonising and modernising the remote Finnmark, while the infrastructure of the Murman area on the Russian side was underdeveloped, to say the least, despite the similar natural conditions of these neighbouring regions. As Jens Petter Nielsen suggests, the interest shown in the development of the Murman area and the Kola Peninsula was a central dimension in the discussions of Russia's future that were activated after defeat in the Crimean War (1853-1856), when Russian governmental circles began to pay attention to the backwardness of Russia in comparison with European countries. After the state border between Sweden-Norway and Russia was drawn along the rivers Pasvikelva and GrenseJakobselv in the 1820s, Finnmark had experienced a considerable demographic and economic growth with blooming fisheries, telegraph communication, and a coast liner service. The Murman area, in turn, had remained as it had been: a remote area with small diverse ethnic groups and no industrial enterprises or connections to the heartlands of Russia ${ }^{8}$.

5 See Anton A. Fedyashin, Liberals under Autocracy. Modernization and Civil Society in Russia, 18661904, Madison, University of Wisconsin Press, 2012, and Sviatoslav Kaspe, "Imperial Political Culture and Modernization in the Second Half of the Nineteenth Century", in Russian Empire. Space, People, Power, 1700-1930, A. V. Remnev et al. (eds.), Bloomington, Indiana University Press, 2007, p. 455-493.

6 On the reception of Scandinavian literature in Russia at the turn of the century, see Nils-Åke Nilsson, "The Reception of Strindberg in Russia: The Introductory Years", Russian Literature, XL (3), 1996, p. 231-254, and Lillian Jorunn Helle, "Ibsen in Russia Revisited: The Ibsenian Legacy in the Symbolist World of Andrei Belyi”, Poljarnyj vestnik: Norwegian Journal of Slavic Studies, vol. 19, 2016, p. 1-14.

7 See E. P. Petrova, Mir iskusstva. K stoletiiu vystavki russkikh i finliandskikh hudozhnikov 1898 goda, Saint Petersburg, Palase, 1998.

8 Jens Petter Nielsen, "The Murman Coast and Russian Northern Policies ca. 1855-1917", in In the North My Nest is Made. Studies in the History of the Murman Colonization 1860-1940, Saint PetersburgTromsø, European University at Saint Petersburg - University of Tromsø, 2005, p. 11-13 and 15-18. 


\section{SERgei WitTe AND his ENTOURAGE}

In 1894, Sergei Witte organised a three-week expedition to the European Russian North and the North of Scandinavia in order to define the possibilities for establishing a naval port at the Kola Peninsula and to acquaint himself with the infrastructure of Arctic Norway. Witte planned the journey in co-operation with the industrialist Savva Mamontov, a leading patron of the arts, who had an important influence on the development of Russian visual arts at the turn of the century. The entourage also included draughtsmen, the youngish painters Konstantin Korovin and Aleksandr Borisov, whose task was to preserve on canvas the impressions that the Northern landscape and towns made on the explorers, and the experienced journalist-writer Evgeni Kochetov, who wrote travel notes during the journey and published them as a book in the following year under the pseudonym Evgeni Lvov.

Witte is a leading figure in the processes of Russian modernisation. As Minister of Finance during the 1890s, he presided over rapid industrialisation and the construction of an extensive railroad network; in 1905, after framing the October Manifesto, he became Prime Minister and designed the first constitution of Russia ${ }^{9}$. Under Witte's supervision, the Russian railroad network was extended to cover areas that were previously seen as remote but which Witte saw were crucial for both economic and military purposes. An important dimension in this respect was the European Far North. There was a continuous discussion during the latter half of the nineteenth century about the necessity to establish an all-year open naval port either on the Murman coast at the Northern side of the Kola Peninsula by the Barents Sea or in the Latvian port town of Libau by the Baltic Sea. The St. Petersburg and Arkhangelsk harbours froze during the winter, so Russia was looking for a secure all-year open harbour not too far from the Russian heartlands that would be able to resist blockades. Witte preferred Ekaterina harbour on the Murman coast (near the town of Murmansk, which was established later on), while the War Ministry and the Naval Ministry argued for the more central Libau. In order to establish a naval port on the Murman coast, the Russian railway network would have needed to be extended to Arkhangelsk and all the way to the Kola Peninsula ${ }^{10}$.

Witte's interest in the journey to the North in 1894 were hence in the main economic and military. The patron of the arts Savva Mamontov, in turn, apparently had both economic and aesthetic reasons for participating in Witte's expedition.

9 On Witte's career, see Francis W. Wcislo, Tales of Imperial Russia. The Life and Times of Sergei Witte, 1849-1915, Oxford, Oxford University Press, 2011.

10 Andy Bruno, The Nature of Soviet Power. An Arctic Environmental History, New York, Cambridge University Press, 2016, p. 37-42. 
As an industrialist, Mamontov was drawn to railways. He was the director of one of the first Russian railway lines, the Moscow-Yaroslavl railway, and supervised the construction of the Severnaia Railway that linked Moscow via Yaroslavl to Vologda. He was also to become supervisor of railway construction from Vologda to Arkhangelsk by the White Sea, which commenced immediately after Witte's and Mamontov's journey to the North. As a patron of the arts, Mamontov was in particular interested in encouraging the development of Russian national art in the spirit of National Romanticism. His family estate, Abramcevo, was an artists' colony that attracted the leading turn of the century artists, including Konstantin Korovin, Ilia Repin, Valentin Serov, and Mikhail Vrubel. Of these artists, Korovin took part in the expedition, and his works from the 1890s are strongly influenced by his travels to the Murman coast. Under Mamontov's supervision, Korovin also designed the Pavillion of the Far North at the 1896 All Russia Exhibition that was held in Nizhny Novgorod. Korovin returned to the Kola Peninsula and Northern Norway later in the same year with Valentin Serov, and Korovin's and Serov's paintings and sketches from the North are employed as illustrations of Out in the Arctic Sea. Later in the 1890s, Korovin and Serov joined Mir iskusstva, the leading Russian visual arts group at the turn of the century; Mir iskusstva organised, for example, the famous exhibitions of Scandinavian and Finnish art in St. Petersburg in 1897 and 1898. Aleksandr Borisov, the other painter taking part in the journey, dedicated his life to Arctic landscape painting and exploration ${ }^{11}$.

Evgeni Kochetov, who used the pseudonyms Evgeni Lvov or Russki strannik (A Russian Stranger), was a well-known journalist who had travelled extensively both within the Russian Empire and abroad when working as a correspondent for the leading conservative journal The New Times. Apparently, Kochetov was not hired by the Finance Ministry to write the travelogue but took part in the journey out of his own interest. Even though one can sense that Kochetov may have more conservative views on such issues as emancipation and constitutional monarchy, the views he expresses in the travelogue are in the main very close to Witte's, whom he depicts as a person of exceptional skills in all possible areas.

There was a great interest among the public in Arctic expeditions at the time, and such journeys as Fridtjof Nansen's Fram expedition in 1893-1896 that aimed at reaching the North Pole from the New Siberian Islands with the help of the

11 On Borisov, see Otto Boele, “The Arctic in Russia's Fin-de-Siècle Imagination: The Paintings and Writings of Aleksandr Borisov", in Russia's Far North. The Contested Energy Frontier, V.-P. Tynkkynen et al. (eds.), London - New York, Routledge, 2018, p. 216-227. 
east-west current of the Arctic Ocean were intensely followed also in Russia ${ }^{12}$. Although Witte's expedition was not a scientific expedition - and not too adventurous either, as it only followed the Norwegian coastal line after leaving Russia - his position and plans for the railway ensured that the trip was closely followed in newspapers. Kochetov published his travel notes as a series of essays simultaneously with the journey in The New Times, so readers were able to follow the journey almost in real time. The route of the expedition was from Arkhangelsk via the Solovetsky Islands to the Kola Peninsula and then towards the Arctic Ocean and Norway. In Norway, the entourage stopped first in Vardø and then continued following the coastal line to the North Cape, Hammerfest, Tromsø and Trondheim, in all of which the travellers stayed for a day or longer. Finally, they took the train from Trondheim to Stockholm, from where they continued by ship to Turku in Finland and then back to St. Petersburg by train. The entourage was received very formally and politely everywhere due to Witte's position, even though it is apparent that the travellers from time to time experienced some tension in the ways in which they, as representatives of the conservative Russian Empire, were perceived by local people.

\section{AN EMPTY PERIPHERY VS EUROPEAN CIVILISATION}

One recurring element that looms large in Russian late nineteenth-century travelogues depicting the European Russian North is the way in which the area is represented in terms of emptiness and stagnation. The Northern landscape is often depicted as if it is asleep, as an empty space that however boasts natural resources that could be utilised for the benefit of the entire Empire, and as a space that waits to be filled with people, civilisation, and, in particular, technological progress such as the railway. Hence, for example, the governor of the Arkhangelsk area, Aleksandr Engelgardt, describes the economic and industrial life of Russian North in his travelogue Russki sever (1897) in terms of "lethargic" sleep: "[Э]кономическая и промышленная жизнь этого обширного края находится в полном застое и как бы влетаргическом сне" ("[T] he economic and industrial life of this huge area is in the state of complete stagnation and as if in lethargic sleep ") ${ }^{13}$. Emptiness and stagnation also characterise the Russian

12 The Fram expedition also fed the Russian literary imagination. The Symbolist Konstantin Balmont's 1896 poem "Mertvye korabli ("The Dead Ships", 1896), describes explorers' ships trapped in the pack ice - perhaps forever -, and Anton Chekhov, who was particularly interested in scientific explorations and carried out one himself, is known to have planned a play loosely based on Nansen's voyage. See Olga L. Knipper-Chekhova, Vospominaniia i stati. Perepiska s A. P. Chekhovym, V. Ia. Vilenkin (ed.), Moscow, Iskusstvo, 1972, p. 61.

13 Aleksandr P. Engelgardt, Russki sever. Putevie zapiski, Saint Petersburg, Izdanie A. Suvorina, 1897, p. 13. All translations are by the author. Engelgardt's travel notes have also been published in English as A Russian Province of the North, Westminster, A. Constable and Co, 1899. 
North in Lvov-Kochetov's description. Nevertheless, these phenomena are viewed not only in negative terms, as emptiness in the travelogue is also associated with silence and the enchanted beauty of the area, which the Witte entourage fills with their actions. Kochetov describes, for example, how at one particular instance the travellers are sitting on a rock by the sea and watching the midnight sun hanging over the horizon. The natural environment around them is described as empty, silent and completely still. Suddenly, Savva Mamontov sees a large bird trying to catch a fish from the seagulls and fires his gun towards the bird, which dies and plunges into the sea. In Lvov-Kochetov's wording, the effect of Mamontov's deed is "enlivening" (rather paradoxically from the poor bird's point of view), and he describes how suddenly the silent and deadly stagnant atmosphere, the water, the fjord and the fjells, are full of life and noise ${ }^{14}$.

The Russian North seen as an empty, stagnant space waiting to be filled with action reflects the nineteenth-century Russian hierarchy of centre and periphery, in which the central geographical and imaginative opposition lies between the capital cities and the provinces. This opposition can be seen both in nineteenthcentury travel writing and in fictional literature, in which St. Petersburg and Moscow epitomise dynamic motion and progress, while the provinces are associated with stagnation and outdated ways of thought and are often described metaphorically in terms of deadly emptiness ${ }^{15}$. In Lvov-Kochetov's description, the Witte entourage represents the very centre of Russian society, its governmental and economic headquarters, while the Russian North stands for an extreme form of periphery. Hence, the opposition between the centre and the periphery in the travelogue is not merely geographical but also has cultural and societal dimensions.

In this regard, the difference between the ways in which Northern Norway and Northern Russia are positioned in the travelogue in relation to Europe deserves particular attention. While Lvov-Kochetov describes Russian Far North as an extremely remote area far away from civilisation, the Scandinavian side is viewed as an integral part of Europe. This comparison is repeatedly made in the travelogue, starting from the expedition's arrival to the Norwegian coast, which is described in terms of arriving from wilderness to Europe: "[Ч]ерез несколько часов мы, после недельного пребывания в оторванной от мира

14 Evgeni Lvov-Kochetov, Po Studenomu moriu. Poezdka na sever. Yaroslavl, Vologda, Arkhangelsk, Murman, Nord-Kap, Trondgeim, Stokgolm, Peterburg, Moscow, Tovarishchestvo tipografi A. I. Mamontova, 1895 , p. 180.

15 See, for example, Vladimir V. Abashev, Russkaia provinciia. Mif-tekst-realnost, Moscow - Saint Petersburg, Nauchnyi sovet po mirovoi kultury Rossiiskoi Akademi Nauk, 2000, and Iu. V. Domanski, "Oppoziciia 'stolica / provinciia' v rasskaze 'Dama s sobachkoi”", in Stati o Chekhove, Tver, Tverski Gosudarstvennyi Universitet, 2001, p. 16-22. 
пустыне, приближались к европейскому городу с телеграфом, почтой, газетами..." "'In a couple of hours we were finally arriving in a European town - with the telegraph, post office, and newspapers - after a week in emptiness, remoteness from the world..." ${ }^{16}$. A similar positioning is also reflected in Konstantin Korovin's paintings from his two journeys to the North in 1894. His paintings of the Kola Peninsula are often landscapes without human presence; in paintings where local villages or people are depicted, they are represented as a part of nature. In Murmanski bereg (The Murman coast, 1894), for example, huge rocks and a sandy beach frame the painting, and the fishermen's cottages and boats appear very small in relation to the natural surroundings that dominate the landscape. In Korovin's paintings of Arctic Norway, in turn, it is in the main not nature but civilisation that is at the centre. One of his most famous works, Gammerfest. Severnoe siianie (Hammerfest. Northern Lights, 1894-1895) depicts Hammerfest harbour and its fishing boats illuminated not only by the Northern lights but also by streetlamps. As a result, one of the northernmost towns in the world appears in Korovin's depiction not as a remote Arctic village but as a charming and cosy European town, which could just as well be situated somewhere in the Netherlands or in France.

The difference in the positioning of centre and periphery concerns not only the relations of the Northern regions to Europe but also the ways in which Northern Norway and Northern Russia are viewed in the countries' respective national imagination. Lvov-Kochetov sees that the main reason behind the ideal organisation of the Norwegian communities and the abject organisation of the Russian communities is their positioning within the respective country's internal hierarchy. The fact that even the more remote cottages are provided with telegraph cables and in the summertime visited by packet boats means, in his view, that in Norway the Arctic areas are not considered to be a periphery as they are in Russia but are viewed as constituting an important part of the country as any town in the South ${ }^{17}$. Similarly, he sees that the fishing and whaling industry in Finnmark is an outcome of governmental concern and interest in the Northern regions and proposes that this should be considered a model for organising fishing in Northern Russia ${ }^{18}$. Hence the geographical opposition between centre and periphery that is crucial in nineteenth-century Russian travel writing and fiction in Lvov-Kochetov's description of the Arctic regions concerns only the Russian side: the Murmansk area appears to be an extreme form of the Russian peripheral province both in terms of its geographical location and positioning in the national imagination.

16 Evgeni Lvov-Kochetov, Po Studenomu moriu, op. cit., p. 203.

17 Ibid., p. 211.

18 Ibid., p. 206. 


\section{DARKER SIDES OF SCANDINAVIAN MODERNITY: TOURISM, ALCOHOLISM AND EMANCIPATION}

As we have seen, arctic Norway is described in the travelogue in positive terms, as a developed, civilised society that has a central place in the national imagination. This representation stands in contrast to the imagery of the Russian Far North that represents darkness, wilderness and the periphery. The opposition between these two Norths in the narration follows the lines of discussions on the development of the Russian Far North according to the Norwegian model. However, there is also another kind of opposition between Arctic Norway and the North of Russia in the travelogue, which also concerns nature and culture. LvovKochetov considers that the main difference between these two Norths is that northern Scandinavia is full of people and culture, while what characterises the Russian North is the absence of people and the overwhelming presence of nature, a dimension that is also present in Korovin's paintings. What is interesting is that in Lvov-Kochetov's travelogue culture acquires not only positive characteristics but is also depicted in terms of disenchantment and inauthenticity, which find resonance in fin-de-siècle discussions on modernity.

In this regard, the way in which Arctic tourism is represented in the travelogue deserves particular attention. When the Witte entourage travels to Northern Norway, Arctic tourism had already developed from a form of travelling that only the privileged few were able to afford into large-scale mass tourism. In the 1880 s and 1890s, the northernmost shores of Norway, the Tromsø fjords and the North Cape, were the most popular Arctic destinations in Europe; even journeys to Spitsbergen and Greenland were organised ${ }^{19}$. Lvov-Kochetov describes English tourists who wander around Tromsø in their yellow wellingtons and desperately try to catch a sight of a whale with their binoculars ${ }^{20}$. He views tourists with a critical eye, and some of the ironic descriptions of mass tourism to the North Cape present the state of modern man in sinister terms:

Отсюда проведен подводный кабель в Европу, здесь туристы пристают на пароходах и по высеченным в скале зарубкам, держась за проволочныи канат, употребляют полтора часа, чтобы взобраться на высшее плато черной скалы и в июне в шубах, дрожа от холода под постоянным леденящим ветром, посмотреть поближе на полуночное солнце $и$ выпить стакан продающегося здесь шампанского. Да, “человеческий разум достигает всего, и побеждает все”! Но не преувеличиваем ли мы значение и смысл этих побед и не слишком ли громко трубим о них, и

19 B. Stonehouse, J. M. Snyder, Polar Tourism. An Environmental Perspective, Bristol, Channel View Publications, 2010, p. 27-28.

20 Evgeni Lvov-Kochetov, Po Studenomu moriu, op. cit., p. 212-213. 
говоря частно о Норд-Капе: не так ли мизерны стоящие сейчас на нем победители вселенной, как ничтожны вон эти чайки, реющие над этими ледяными водами, а между тем чайки легко поднимаются значительно выше площадки Норд-Капа и таким образом самостоятельно при помощи одних только крыльев, дарованных им самой природой, во всякое время и безо всяких приспособлений, риска и неудач ближе к вечному солниу и Твориу, его зажегшему... ${ }^{21}$

There is a submarine cable from here to Europe; it is here the tourists hop off from the yachts and spend an hour and a half climbing to the highest point of the black rocks with the help of notches that have been carved in the rocks and a long rope, all freezing in their fur coats in the middle of the summer as the wind is constantly from the Arctic Ocean, and all just to be able to have a closer look at the midnight sun and drink a glass of champagne that is on sale here. Yes, "the human reason is able to reach anything and gains victory over everything"! But are we not exaggerating the importance and meaning of these victories, are we not boasting about them in too loud a voice - and I am talking here about the North Cape, in particular: are not the winners of the globe that are now standing on the rocks as pitiful as are those insignificant seagulls who soar there over these Arctic waters? Moreover, it is easy for the seagulls to rise considerably higher than the summit of the North Cape; and besides, they are able to do this independently, only with the help of their wings which nature has given them; they are able to get closer to the eternal sun and the Creator who has lit it at any time and without any assistance, risk or failure...

The concluding chapter of the travelogue describes the travellers' journey from Trondheim to Stockholm by train - a journey that Witte and Mamontov consider most convenient because of the high quality of the train services, which they find have a lot to offer for the development of railway construction back home $^{22}$. When the entourage arrives in Stockholm and views the capital on foot, Lvov also discusses the national identity of the Swedes. He sees Sweden as a country with a splendid past but a negligible present, concluding rather pejoratively that Stockholm is a nice city, even though it has no national identity but merely imitates other Western European cities ${ }^{23}$. There is a tangible national element in this criticism: clearly Lvov-Kochetov sees that Russians have an easily distinguishable national identity, and that Russia as a nationstate has a bright future. Lvov-Kochetov's description of Stockholm, in turn, includes darker shades: he sees that the previous glory of the Swedish Empire has vanished on account of social emancipation, and his description of urban Swedish life introduces elements of degradation. The main problems of this

21 Ibid., p. 210, emphasis original.

22 Ibid., p. 220.

23 Ibid., p. 227-228. 
post-emancipation society, as Lvov-Kochetov calls Sweden, are illegitimate children and alcoholism, which he sees are the inevitable outcome of liberalist ideas and politics ${ }^{24}$. The lively atmosphere of Stockholm's bars and restaurants with their female serving staff reflects in his description the miserable state of the Swedish capital: "[Ш]ведская столица начинает пить с 12 часов дня, ак вечеру Бахус и Эрот всеиело завладевают жителями” (“[T]he Swedish capital starts drinking at noon, and already in the evening its inhabitants have been demonised by Bacchus and Eros") ${ }^{25}$. These views reflect the scepticism that was felt towards Scandinavian liberal politics in Russia at the turn of the century. While in Western-orientated circles, Scandinavia was seen as a positive example of modernisation in terms of economic development, Lvov-Kochetov's criticism shows that social emancipation and democratisation were not necessarily seen as an integral part of the processes of modernisation.

\section{Conclusion}

Out in the Arctic Sea reflects governmental discussions on the modernisation of the Murman area during the last decades of the nineteenth century. Comparisons between the Russian North and Northern Norway are apparent throughout Lvov-Kochetov's travelogue. In terms of Russian economic modernisation, Arctic Norway is represented as a model for the future development of the Murman and Arkhangelsk areas. What separates Lvov-Kochetov's travelogue from some other travel accounts of the North is the way in which it not only boosts economic modernisation but also acknowledges and critically reflects on such discourses and practices of Arctic modernity as mass tourism.

Witte's expedition had some immediate results. The railway line from Vologda to Arkhangelsk was built according to his plans already in 1896, and in the same year, a telephone and a telegraph line were extended to Kola, improving communication with the mainland ${ }^{26}$. However, despite the fact that Tsar Alexander III had agreed with Witte's plans to establish the new naval port on the Murman coast, Libau in Latvia was finally chosen for the new naval port, since railway construction all the way to the Kola Peninsula was considered too expensive ${ }^{27}$. Witte's plans were, however, realised a couple of decades later, during World War I, when Russia and her allies needed an alternative route for the Vologda-Arkhangelsk railway to the North. The railway was extended to the

24 Ibid., p. 228.

25 Ibid., p. 229.

26 Aleksandr P. Engelgardt, Russki sever, op. cit., p. 26.

27 Sergei Witte, The Memoirs of Count Witte, transl. Sidney Harcave, New York - Toronto, Doubleday - Page \& Co, 1921, p. 180. 
peninsula and the city of Murmansk established in 1916, and from the 1920s on, when the natural resources of the area started to be exploited in full, the Kola Peninsula became one of the main areas of Soviet expansion, industrialisation and urbanisation. After this colonisation process, which had catastrophic consequences for the natural environment and the indigenous peoples of the Kola Peninsula, the Murman area certainly did not lag behind the neighbouring Finnmark in terms of modernisation ${ }^{28}$.

28 For industrialisation and the transformation of the ecosystem on the Kola Peninsula, see Andy Bruno, The Nature of Soviet Power, op. cit., p. 73-120. 